\title{
New journals June 1983 to May 1984
}

CRITERIA for journals to be considered for review in this issue were circulated to publishers earlier this year, and were also published in Nature. They were that:

(i) the first number appeared, or the journal was re-titled, between June 1983 and May 1984 (although journals not covered in last year's review issue were also considered) ${ }^{*}$

(ii) the journal is published at least three times a year (one exception has been made to this rule);

(iii) the main language used is English;

(iv) where possible at least four issues should be made available for review, including the first and the most recent.

Last year's journals review supplement covered publications appearing between June 1982 and May 1983 and the second cut-off date, May 1984, allows for enough issues of a journal to have been published for a reasonable sample to be available for judgement (most are quarterlies). A spread of four different issues is taken as

* See Nature 311, 309-330 (1984). For previous journals review supplements see Nature 305 , $477-497(1983) ; 299,491-514(1982)$; and 293, $341-369(1981)$

\section{Index to reviews}

Adsorption Science \& Technology

AIDS Research

The Antimicrobic Newsletter

Archives of Insect Biochemistry and Physiology

BioEssays

Biogenic Amines

Biology and Society

Biotechnology Advances

Classical and Quantum Gravity

Cognitive Neuropsychology

Complement

Critical Reviews in

Biotechnology

Critical Reviews in Oncology/

Hematology

Disease Markers

European Biophysics Journal

Experimental Biology: Environmental and Sensory Aspects

Experimental and Clinical Immunogenetics

Food Microbiology

Gene Analysis Techniques

Genetic Epidemiology

Hematological Oncology

History and Technology

International Journal of Food Microbiology

JMCI: The Journal of Molecular and Cellular Immunology

Journal of Atmospheric Chemistry

Journal of Biomolecular Structure \& Dynamics

Journal of Electron Microscopy Technique

the usual minimum on which reviewers' comments can be based.

Several journals known to satisfy the above criteria were not submitted for review, or arrived only in August or September, and therefore are not covered in this issue. It proved difficult to find reviewers for other, doubtless worthy journals, while some titles were considered to be of marginal interest to Nature's audience.

The brief given to reviewers was to limit themselves to comment on the publications sent to them, and to avoid discussion of general questions of periodical publishing. Opinions expressed in the reviews are based on a sample, and apply to mid1984 at the latest. As in previous years, the preponderance of journals in the biological sciences reflects the bias of material submitted for review.

Details of editors and frequency of publication, and the subscription rates appearing at the top of each review, are given in most instances for 1986. This information is not complete in all cases, and readers interested in subscribing to a particular journal should check the rates with the publisher concerned.

Journal of Environmental

Radioactivity of Surfaces Agriculture

Vaccine

Virus Research
Journal of Experimental Pathology Journal of Inclusion Phenomena

Journal of Neurogenetics

Magnetic Resonance Imaging

Magnetic Resonance in Medicine

Marine and Petroleum Geology

Microbiological Sciences

Mining Science \& Technology

Molecular Biology and Evolution

Natural Product Reports

Neuroscience Research

Physics, Chemistry and Mechanics

Research and Development in

Somatosensory Research

Soviet Journal of Chemical Physics

Zoological Science

305

294 307

303

299

299

305

301

306

296

308

303

307

302

302

308

298

298

300

- Among other titles submitted: Annals of Sports Medicine (Oxford University Press); Blood Purification (Karger); $C_{1}$ Molecule Chemistry (Harwood); Earth, Moon, and Planets, formerly The Moon and the Planets (Reidel); Hazardous Waste (Mary Ann Liebert); Journal of Clinical Neurophysiology (Raven); Journal of Coastal Research (The Coastal Education and Research Foundation, PO Box 2473, Fort Lauderdale, Florida 33303, USA); Journal of Pineal Research (Alan R. Liss); Marine Resource Economics (Crane Russak); Medical Oncology and Tumor Pharmacotherapy (Pergamon); Microcirculation, Endothelium, and Lymphatics (Deerfield Scientific Publishers); Nuclear Engineering and Design/Fusion (North-Holland); Order: A Journal on the Theory of Ordered Sets and its Applications (Reidel); Remote Sensing Reviews (Harwood).
New ground for intrepid explorers ...

An expedition into the recently discovered but still uncharted possibilities of treating or preventing congenital defects. To lay down the first diagnostic, medical, surgical and ethical tracks for future clinicians and researchers to follow.

\section{Fetal Therapy}

Clinical Advances and Basic Research Editors: M. Michejda(Washington, DC) K. Pringle (lowa City, Iowa)

\section{.o Or guided tours over tough terrain}

Leading experts provide a safe escort through the maze of data within their native specialties. And give concise but authoritative commentaries on the major landmarks of current research.

\section{Digestive Diseases}

Current Concepts in Research and Practice Formerly 'Survey of Digestive Diseases'

Editors-in-Chief:

T.S.N. Chen (East Orange, N.J.)

R.K. Zetterman (Omaha, Nebr.)

Immunologic Research

A Selective Reference to Current Research and Practice

Formerly 'Survey of Immunologic Research' Editor-in-Chief:

J.M. Cruse (Jackson, Miss.)

Pathology and Immunopathology Research A Selective Reference to Current Research and Practice

Formerly 'Survey and Synthesis of

Pathology Research'

Editor-in-Chief:

J.M. Cruse (Jackson, Miss.)

Find out more by looking at a sample copy.

Write to

S. Karger AG

P.O. Box

$\mathrm{CH}-4009$ Basel (Switzerland)

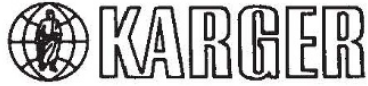

